Article

\title{
Green-Sustainable Recovery of Phenolic and Antioxidant Compounds from Industrial Chestnut Shells Using Ultrasound-Assisted Extraction: Optimization and Evaluation of Biological Activities In Vitro
}

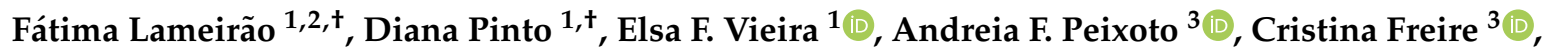 \\ Stefania Sut ${ }^{4}$, Stefano Dall'Acqua ${ }^{4,5}{ }^{\oplus}$, Paulo Costa ${ }^{2}{ }^{\circledR}$, Cristina Delerue-Matos ${ }^{1}{ }^{(\mathbb{D}}$ and \\ Francisca Rodrigues $1, * \mathbb{D}$ \\ 1 Polytechnic of Porto-School of Engineering, REQUIMTE/LAQV, Rua Dr. António Bernardino de Almeida, \\ 4249-015 Porto, Portugal; fatinhalameirao@outlook.com (F.L.); diana.pinto@graq.isep.ipp.pt (D.P.); \\ elsa.vieira@graq.isep.ipp.pt (E.F.V.); cmm@isep.ipp.pt (C.D.-M.) \\ 2 REQUIMTE/UCIBIO, MedTech-Laboratory of Pharmaceutical Technology, Department of Drug Sciences, \\ Faculty of Pharmacy, University of Porto, Rua de Jorge Viterbo Ferreira nº. 228, 4050-313 Porto, Portugal; \\ pccosta@ff.up.pt \\ 3 REQUIMTE/LAQV, Department of Chemistry and Biochemistry, Faculty of Sciences, University of Porto, \\ Rua do Campo Alegre 1021/1055, 4169-007 Porto, Portugal; andreia.peixoto@fc.up.pt (A.F.P.); \\ acfreire@fc.up.pt (C.F.) \\ 4 DAFNAE, Department of Agronomy, Food, Natural Resources, Animals and Environment, University of \\ Padova, Viale dell'Università, 16, Legnaro, PD 35020, Italy; stefania_sut@hotmail.it (S.S.); \\ stefano.dallacqua@unipd.it (S.D.) \\ 5 DSF, Department of Pharmaceutical and Pharmacological Sciences, University of Padova, via Marzolo 5, \\ 35121 Padova, Italy \\ * Correspondence: franciscapintolisboa@gmail.com or francisca.rodrigues@graq.isep.ipp.pt; \\ Tel.: +351-22-83-40-500; Fax: +351-22-83-21-159 \\ + The authors contributed equally to the present work.
}

Received: 2 March 2020; Accepted: 22 March 2020; Published: 24 March 2020

\begin{abstract}
Chestnut processing industry generates large amounts of by-products, including leaves, burs and shells that are a source of bioactive compounds. The purpose of this study was to establish an ultrasound-assisted extraction (UAE) of phenolic and antioxidant compounds from industrial chestnut shells. A central composite design (CCD) was conducted to analyze the effects of time (4-46 min) and temperature $\left(34-76^{\circ} \mathrm{C}\right)$ in the antioxidant activity $\left(2,2^{\prime}\right.$-azino-bis(3-ethylbenzothiazoline-6-sulfonic acid (ABTS), 2,2-diphenyl-1-picrylhydrazyl (DPPH), and ferric reducing antioxidant power (FRAP)) and total phenolic compounds (TPC) of chestnut shells extracts. The optimal extraction conditions were obtained at $70^{\circ} \mathrm{C}$ for $40 \mathrm{~min}$. The optimal extract was characterized regarding phenolic profile, radical scavenging capacity, and effects on intestinal and dermal cell lines. The optimal extract revealed high amounts of ellagic acid $(40.4 \mu \mathrm{g} / \mathrm{mg} \mathrm{dw})$, followed by caffeic acid derivative $(15.4 \mu \mathrm{g} / \mathrm{mg}$ $\mathrm{dw})$ and epigallocatechin $(15.3 \mu \mathrm{g} / \mathrm{mg} \mathrm{dw})$. Indeed, the extract exhibited the highest scavenging efficiencies against $\mathrm{NO} \bullet\left(\mathrm{IC}_{50}=0.1 \mu \mathrm{g} / \mathrm{mL}\right)$ and $\mathrm{HOCl}\left(\mathrm{IC}_{50}=0.7 \mu \mathrm{g} / \mathrm{mL}\right)$ and did not conducted to a decrease on HaCaT and HFF-1 viability up to $100 \mu \mathrm{g} / \mathrm{mL}$. Oppositely, a decrease on Caco-2 and HT29-MTX viability was observed. This study suggests that UAE could be a sustainable option to valorize chestnut shells as raw material for different industries.
\end{abstract}

Keywords: Castanea sativa shells; ultrasound-assisted extraction (UAE); response surface Methodology; phenolics 


\section{Introduction}

Castanea sativa Mill. is a species belonging to Fagaceae family and genus Castanea widely present in Europe. Due to the plurality of applications, not only as food but also as source of wood for wine industry, this species is outstanding, representing an important natural resource for rural populations [1]. Chestnut wood is rich in tannins and extremely resistant. Therefore, it is commonly employed in the manufacture of barrels and casks due to its low porosity and sensitivity to temperature variation. Also, the high levels of aldehydes, phenolic, and volatile compounds are extremely important in the wine aging process [2]. The chestnut production is mainly intended for natural consumption or for production of frozen chestnut. Frozen chestnut production normally occurs for fruits with a caliber inferior to $30 \mathrm{~mm}$. However, semi-processed chestnuts are applied in a huge variety of products, such as jams, purees and flour, among others. The chestnut processing procedure can be divided in three steps: (1) calibration; (2) peeling of the outer shell at high temperatures and (3) removal of the inner shell by water vapor and mechanical processes. Subsequently, the fruits are sorted, manually checked and frozen. During this process, several by-products are generated, mainly shells (inner and outer). Outer and inner shells represent, respectively, $1.5-8.9 \%$ and $6.3-10.1 \%$ of the total weight of fresh fruit [3]. According to different authors, the main phenolic compounds present in chestnut shells are phenolic acids (ellagic and gallic), flavonoids (rutin, quercetin and apigenin), and tannins [3-5]. Phenolic acids, namely ellagic and gallic acid, have been linked to potential health benefits including antioxidant, anticarcinogenic, and anti-inflammatory activities and decrease of cardiovascular disease risk [6-8]. Indeed, flavonoids exert numerous biochemical and pharmacological activities, being associated with the increase resistance of blood vessels, treatment of chronic venous insufficiency and improvement of microvascular blood flow $[9,10]$. According to Morana et al., the inner shell can contain between $2.7 \%$ and $5.2 \%$ of phenolic compounds [11]. Aires et al. reported that the main phenolic compounds present in aqueous extracts of chestnut shells are gallic acid, ellagic acid, vescalagin, castalagin, epigallocatechin, catechin, and epicatechin [12]. Nevertheless, the bioactive compounds obtained from natural sources depends on the extraction process employed.

Extraction processes are widely used by different industries, such as food, pharmaceutical or cosmetic. In order to reduce production costs and optimize processes, new technologies-such as ultrasound-assisted extraction (UAE) - have been employed to decrease energy consumption and increase the product or process safety/control and quality [13,14]. In fact, conventional techniques (such as Soxhlet extraction or maceration) have long been used to extract bioactive compounds from natural matrices [15]. However, these traditional methods have associated disadvantages, such as low extraction rate, use of large amounts of solvents and high energy consumption [16]. Thus, the implementation of green extraction techniques is a challenge. The UAE is based on the production of longitudinally directed ultrasonic vibrations towards sample (sound waves with frequencies above $20 \mathrm{kHz}$ ) capable of causing cavitation [14]. The physical cavitation process generated leads to the formation, growth and collapse of microbubbles within the liquid phase, which facilitate the solvent penetration and improve heat and mass transfer by rupturing cell walls $[14,17,18]$. Bubble collapse produces extremely high temperatures and pressures, approximately $5000^{\circ} \mathrm{C}$ and $100 \mathrm{MPa}$, respectively $[19,20]$. Two systems are available for UAE: (1) ultrasound probe and (2) ultrasound bath. Both systems have a transducer that converts mechanical or electrical energy into sound energy (ultrasonic waves) [13]. The ultrasonic bath is a cheap, easy-to-operate device that spans a large number of samples [13]. However, when compared to the probe system, it has a lower cavitation efficiency [14]. On the other hand, the ultrasound probe is generally preferred as it has a direct effect on sample while in the ultrasound bath the effect produced is indirect, as the wavelength of the sound acts in the container before reaching the sample [21]. When compared, the ultrasonic probe has the advantage of producing more energy (allowing a faster extraction), mainly due to the direct immerse in the solution, increasing the contact area with the material and reducing the resistance in the mass transfer [14]. In contrast to conventional extractions that are not suitable to be implemented in a large-scale, an upscale of UAE represents a feasible technological alternative for industrial applications. 
The interest for this eco-friendly technique has been increasing in the last decades with some companies using it to produce extracts from natural sources $[13,22,23]$. UAE has emerged as an efficient, rapid, energy and time-saving, and clean extraction methodology, providing a higher recovery of bioactive compounds using low amounts of solvent $[13,22,23]$. As an example, Pan et al. extracted polyphenols from pomegranate peels using UAE and described a reduction of $87 \%$ of extraction time and an increase of $22 \%$ in the antioxidant activity compared to the extracts obtained by maceration [24]. Pingret et al. performed lab- and pilot-scale UAE extraction of polyphenols from apple pomace and reported a stronger antioxidant activity and a total phenolic content $30 \%$ higher than the one determined for conventional extraction [25]. To the best of our knowledge, no studies report the use of UAE for the extraction of bioactive compounds from C. sativa shells (CSS). This paper was designed to extract active ingredients from CSS using UAE as eco-friendly technology in order to valorize this by-product and aware industry for a new potential ingredient. The extraction was optimized by response surface methodology (RSM) with view to obtain an extract with high antioxidant activity. Indeed, the phenolic profile was assessed to understand individual phenolic compounds responsible for the activity, as well as radical scavenging activity and in vitro effects on different intestinal and skin cells.

\section{Materials and Methods}

\subsection{Chemicals}

All chemical reagents, solvents and standards were of analytical reagent grade and obtained from Sigma-Aldrich (St. Louis, MO, USA). Standards used for the quantification or for the identification of compounds, namely by LC-MS, were purchased from Sigma-Aldrich (Steinhemin, Germany) and Extrasynthese (Genay Cedex, France).

\subsection{Sample}

Castanea sativa shells were kindly supplied by Sortegel, located in Sortes (Bragança, Portugal, latitude $41^{\circ} 42^{\prime} 18.6^{\prime \prime} \mathrm{N}$ and longitude $6^{\circ} 48^{\prime} 36.6^{\prime \prime} \mathrm{W}$ ), in October 2018. Shells were dehydrated (Excalibur Food Dehydrator, Sacramento, CA, USA) at $41^{\circ} \mathrm{C}$ for $24 \mathrm{~h}$ and grounded in a miller (Ultra Centrifugal Mill ZM 200, Retsch, Germany) to particles sizes of $1 \mathrm{~mm}$. Afterwards, samples were thoroughly mixed and stored at room temperature $\left(20^{\circ} \mathrm{C}\right)$ and under light-free conditions until extraction.

\subsection{Ultrasound-Assisted Extraction (UAE) of Bioactive Compounds from C. sativa Shells}

The UAE was carried out using an ultrasonic device (Sonic Vibracell, model VC 750, Newtown, CT, USA), comprising a $13 \mathrm{~mm}$ diameter tip with amplitude, temperature and time controller. The amplitude employed was $50 \%$. The powdered samples $(5 \mathrm{~g})$ were extracted with $100 \mathrm{~mL}$ of water into the ultrasonic device at different times and temperatures, as defined by the RSM design. After ultrasonic extraction, the extracts were filtered through Whatman $n^{\circ} 1$ paper, centrifuged (Sigma 3-30KS, Sigma, Osterode am Harz, Germany) at $16,000 \times \mathrm{g}$ for $10 \mathrm{~min}$ and frozen at $-80^{\circ} \mathrm{C}$ for subsequent lyophilization (Telstar, model Cryodos -80, Barcelona, Spain). Samples were stored at $4{ }^{\circ} \mathrm{C}$ until analysis. For the subsequent analyses, the final residue was dissolved in water. 


\subsection{Experimental Design, Modelling, and Optimization of Antioxidant Conditions}

The RSM is employed to modulate and analyze challenges in which the responses studied (dependent variables) are influenced by independent variables. The RSM was applied to optimize the $\mathrm{UAE}$, with the purpose of selecting favorable extraction conditions and maximize the efficiencies to extract bioactive compounds. A central composite design (CCD) was built for optimization of the best extraction conditions to obtain the highest antioxidant activity and phenolic composition. The CCD variables under analysis were time $\left(X_{1}, 4,10,25,40\right.$, and $\left.46 \mathrm{~min}\right)$ and temperature $\left(X_{2}, 34,40,55,70\right.$, and $76^{\circ} \mathrm{C}$ ). A total of 13 experiments were randomly performed (Table 1$)$. A complete 22-factorial design characterizes $C C D$ that comprises cubic points, with four axial points at a distance of $\alpha=1.414$ from the design center, and five center points. The Total Phenolic Content (TPC; $Y_{1}$ ) and the antioxidant activity analyzed by ferric reducing antioxidant power (FRAP) $\left(Y_{2}\right)$, 2,2-diphenyl-1-picrylhydrazyl $(\mathrm{DPPH})\left(Y_{3}\right)$, and 2,2'-azino-bis(3-ethylbenzothiazoline-6-sulfonic acid (ABTS) $\left(Y_{4}\right)$ assays were the responses studied. The analysis of the regression equations, response surfaces, and contour plots using the predictive equations of RSM allows the determination of the optimal values of $Y$ responses. A set of experiments using the critical values optimized were carried out to evaluate the accuracy of the models. In this way, a t-test was employed to compare the responses under optimized conditions with those predicted by CCD model. 
Table 1. Experimental and predicted values of total phenolic compounds (TPC) (mg gallic acid equivalents (GAE)/g dw), FRAP (IC $50 \mu \mathrm{g} / \mathrm{mL}), \mathrm{DPPH}(\mathrm{IC} 50 \mu \mathrm{g} / \mathrm{mL})$, and ABTS $\left(\mathrm{IC}_{50} \mu \mathrm{g} / \mathrm{mL}\right)$ of $C$. sativa shells extracts obtained by central composite design (CCD).

\begin{tabular}{|c|c|c|c|c|c|c|c|c|c|c|c|}
\hline \multirow[b]{3}{*}{ Exp. } & \multirow{3}{*}{$\begin{array}{c}X_{2} \text { Time } \\
(\mathrm{min})\end{array}$} & \multirow{3}{*}{$\begin{array}{c}\begin{array}{c}X_{1} \text { Temp. } \\
\left({ }^{\circ} \mathrm{C}\right)\end{array} \\
X_{2}\end{array}$} & \multirow{2}{*}{\multicolumn{2}{|c|}{$Y_{1}$ TPC (mg GAE/g dw) }} & \multicolumn{6}{|c|}{ Antioxidant Activity } & \multirow{3}{*}{ Yield (\%) } \\
\hline & & & & & \multicolumn{2}{|c|}{$\gamma_{2} \operatorname{FRAP}\left(\mathrm{IC}_{50} \mu \mathrm{g} / \mathrm{mL}\right)$} & \multicolumn{2}{|c|}{$Y_{3}$ DPPH $\left(\mathrm{IC}_{50} \mu \mathrm{g} / \mathrm{mL}\right)$} & \multicolumn{2}{|c|}{$\gamma_{4}$ ABTS $\left(\mathrm{IC}_{50} \mu \mathrm{g} / \mathrm{mL}\right)$} & \\
\hline & & & Experimental $^{\mathrm{a}}$ & Predicted $^{b}$ & Experimental $^{\mathrm{a}}$ & Predicted $^{b}$ & Experimental a $^{\mathrm{a}}$ & Predicted $^{b}$ & Experimental $^{\mathrm{a}}$ & Predicted $^{b}$ & \\
\hline 1 & 10 & 40 & $297.3 \pm 7.6$ & 308.5 & $39.8 \pm 1.4$ & 38.7 & $56.5 \pm 0.1$ & 53.4 & $66.4 \pm 4.9$ & 61.6 & $7.3 \pm 1.2$ \\
\hline 2 & 40 & 40 & $350.5 \pm 13.1$ & 372.2 & $36.5 \pm 2.8$ & 33.9 & $59.9 \pm 3.5$ & 56.3 & $69.6 \pm 1.5$ & 66.0 & $11.5 \pm 0.4$ \\
\hline 3 & 10 & 70 & $358.6 \pm 9.0$ & 337.2 & $36.1 \pm 1.5$ & 37.7 & $56.7 \pm 2.1$ & 58.4 & $64.4 \pm 4.1$ & 59.9 & $8.1 \pm 0.1$ \\
\hline 4 & 40 & 70 & $393.1 \pm 14.0$ & 382.2 & $32.0 \pm 1.5$ & 32.1 & $44.1 \pm 3.4$ & 45.5 & $65.3 \pm 5.6$ & 62.1 & $16.1 \pm 2.5$ \\
\hline 5 & 4 & 55 & $255.8 \pm 4.7$ & 263.1 & $45.3 \pm 0.1$ & 44.8 & $63.7 \pm 5.2$ & 64.3 & $50.5 \pm 0.5$ & 55.4 & $8.3 \pm 0.7$ \\
\hline 6 & 46 & 55 & $347.6 \pm 9.0$ & 340.0 & $36.0 \pm 2.1$ & 37.5 & $56.1 \pm 3.3$ & 57.2 & $57.0 \pm 3.5$ & 60.2 & $10.3 \pm 0.1$ \\
\hline 7 & 25 & 34 & $408.0 \pm 20.3$ & 384.8 & $28.7 \pm 0.1$ & 31.1 & $43.7 \pm 3.2$ & 48.1 & $64.7 \pm 5.0$ & 69.0 & $11.7 \pm 1.6$ \\
\hline 8 & 25 & 76 & $389.4 \pm 23.6$ & 412.2 & $30.5 \pm 1.4$ & 29.1 & $46.7 \pm 2.0$ & 44.0 & $61.3 \pm 2.3$ & 65.1 & $13.4 \pm 0.9$ \\
\hline 9 & 25 & 55 & $360.3 \pm 8.4$ & 356.0 & $36.2 \pm 2.2$ & 36.3 & $55.4 \pm 1.9$ & 57.2 & $87.7 \pm 3.0$ & 80.6 & $10.9 \pm 1.5$ \\
\hline 10 & 25 & 55 & $336.0 \pm 22.9$ & 356.0 & $36.5 \pm 0.7$ & 36.3 & $51.5 \pm 2.1$ & 57.2 & $71.8 \pm 0.1$ & 80.6 & $8.5 \pm 1.7$ \\
\hline 11 & 25 & 55 & $365.5 \pm 9.9$ & 356.0 & $35.4 \pm 1.3$ & 36.3 & $57.7 \pm 1.1$ & 57.2 & $72.6 \pm 1.9$ & 80.6 & $11.4 \pm 6.7$ \\
\hline 12 & 25 & 55 & $355.1 \pm 16.7$ & 356.0 & $38.8 \pm 1.5$ & 36.3 & $58.8 \pm 0.1$ & 57.2 & $88.0 \pm 3.0$ & 80.6 & $8.6 \pm 1.9$ \\
\hline 13 & 25 & 55 & $363.1 \pm 9.6$ & 356.0 & $34.7 \pm 1.3$ & 36.3 & $62.8 \pm 4.3$ & 57.2 & $83.0 \pm 5.5$ & 80.6 & $9.3 \pm 0.8$ \\
\hline
\end{tabular}

$\mathrm{a}, \mathrm{b}$ Experimental values, performed in a random order and expressed as the average of triplicate determinations from different experiments $(n=3)$. IC $\mathrm{C}_{50}=\mathrm{In}$ vitro concentration required to decrease in $50 \%$ the reactivity of the studied reactive species. 


\subsubsection{ABTS Radical Scavenging Activity Assay}

The ABTS radical scavenging activity of extracts was evaluated according to Re et al. [26], with minor modifications. A calibration curve was obtained using known concentrations of ascorbic acid as standard (linearity range: $5-100 \mu \mathrm{g} / \mathrm{mL}, R^{2}>0.993$ ). The results were expressed in terms of $\mathrm{IC}_{50}$ (extract concentration providing $50 \%$ of radical scavenging activity).

\subsubsection{Ferric Reducing Antioxidant Power (FRAP) Assay}

Ferric reducing antioxidant power was determined according to Benzie and Strain [27], with minor modifications. Results were expressed in terms of $\mathrm{IC}_{50}$ (extract concentration providing $50 \%$ of radical scavenging activity).

\subsubsection{DPPH Free Radical Scavenging Assay}

DPPH free radical scavenging assay was performed according to Barros et al. [28], with minor modifications. The results were expressed in terms of $\mathrm{IC}_{50}$ (extract concentration providing $50 \%$ of radical scavenging activity).

\subsubsection{Total Phenolic Content (TPC)}

The total phenolic content (TPC) quantification was performed based on the Folin-Ciocalteu procedure [29], with minor modifications, being expressed as $\mathrm{mg}$ of gallic acid equivalents (GAE) per gram of plant material on dry weight $(\mathrm{dw})$.

\subsection{Characterization of the Optimal CSS Extract}

\subsubsection{ROS and RNS Scavenging Capacity Assays}

A Synergy HT Microplate Reader (BioTek Instruments, Inc., Winooski, VT, USA), capable to measure fluorescence, chemiluminescence and UV/Vis and equipped with a thermostat, was used to evaluate the reactive oxygen and nitrogen species (ROS and RNS, respectively) scavenging capacity. To obtain the values of $\mathrm{IC}_{50}$, the curves of percentage of inhibition versus extract concentration were analyzed. The superoxide anion radical $\left(\mathrm{O}_{2} \bullet^{-}\right)$, hypochlorous acid $(\mathrm{HOCl})$, peroxyl radical ( $\left.\mathrm{ROO} \bullet\right)$, and nitric oxide (NO•) scavenging capacity assays were performed according to Gomes et al. [30]. Catechin and gallic acid were used as positive controls in the scavenging assays. Samples were prepared as previously described by Marangi et al. [31].

2.5.2. Identification of Phenolic Compounds by Qualitative and Quantitative Analysis by ${ }^{1} \mathrm{H}$ NMR and LC-UV-MS

NMR analysis were obtained on a Bruker Avance III spectrometer operating at $400 \mathrm{MHz}$. Standard Bruker sequences were used for the acquisition of mono and dimensional experiments. Measurements of $90^{\circ}$ pulse length/power and relaxation delay were performed for each sample. The LC-DAD-MS analysis was performed using two different chromatographic approaches: (i) one using a hydrophilic interaction liquid chromatography (HILIC), on a Tosohas amide $80(2.1 \times 150 \mathrm{~mm}, 3.5 \mu \mathrm{m})$ column and (ii) another employing a reverse phase (C18) stationary phase on a Phenomenex RP-Polar $(3 \times 150 \mathrm{~mm}$, $4 \mu \mathrm{m}$ ) column. For the HILIC, water $1 \%$ formic acid (A) and acetonitrile (B) were used as eluents. Gradient was as follow: start with $99 \%$ of B, in $20 \mathrm{~min} 80 \%$ B, the composition was isocratic up to $25 \mathrm{~min}$, then in $45 \mathrm{~min}$ was changed to $35 \% \mathrm{~B}$ and in $51 \mathrm{~min} 20 \% \mathrm{~A}$. The flow rate was $200 \mu \mathrm{L} / \mathrm{min}$. For the second chromatographic approach, the eluents were as follows: water $1 \%$ formic acid $(\mathrm{A})$ and methanol (B), gradient start with $90 \%$ of A and in $20 \mathrm{~min}$ reach $90 \% \mathrm{~B}$. The flow rate was $0.4 \mathrm{~mL} / \mathrm{min}$. At the end of the HPLC column, a "T" connector splits the flow rate half to DAD, half to mass spectrometer and half to fluorimetric (FLX) or diode array detector (DAD). DAD chromatograms were detected at different wavelengths $(254,280,350 \mathrm{~nm})$ and the UV-VIS spectra were acquired in the range of 
200-600 nm. Fluorescence chromatograms were obtained using excitation at $230 \mathrm{~nm}$ and emission at $320 \mathrm{~nm}$. MS spectra were recorded in negative or in positive ion mode in 50-2000 Da range, using an ESI ion source. The Turbo Data Depending Scanning (TDDS) function of the mass spectrometer was used to study the fragmentation schemes of the prevalent ions detected. The compounds identification was based on the fragmentation spectra, as well as, in the comparison of the mass spectrometric data with literature and injection of reference compounds when available. For quantification purposes, calibration curves of the reference compounds, namely chlorogenic acid (5-100 $\mu \mathrm{g} / \mathrm{mL})$ and rutin $(8-80 \mu \mathrm{g} / \mathrm{mL})$, were obtained by diluting stock standards solution. Linear regressions were as follows: (i) rutin $(280 \mathrm{~nm}), y=11.101 x+0.014\left(R^{2}=0.999\right)$; (ii) chlorogenic acid $(330 \mathrm{~nm}) y=17.11 x-0.121$ $\left(R^{2}=0.999\right)$. For Procyanidin quantification, Procyanidin B1 was used as reference and FLX (ex 230; emission 320) was used for quantification purposes. The calibration curve was obtained in the range $5-50 \mathrm{ug} / \mathrm{mL}$ and the curve equation was $y=0.98 x+0.002\left(R^{2}=0.992\right)$.

\subsubsection{Cells Viability Assay}

The 3-(4,5-dimethylthiazol-2-yl)-2,5-diphenyltetrazolium bromide (MTT) assay was performed to evaluate the effect of the optimal CSS extract on intestinal and skin cell lines. Briefly, cells were incubated during $24 \mathrm{~h}$ with fresh medium in the absence or presence of extracts $(0.1,1,10,100$, and $1000 \mu \mathrm{g} / \mathrm{mL})$ dissolved in cell culture medium. Four cell lines were employed: (i) Caco-2 clone type C2BBe1 cells, provided by American Type Culture Collection (ATCC, Manassas, VI, USA); (ii) HT29-MTX cell line, obtained from Dr. T. Lesuffleur (INSERMU178, Villejuif, France); (iii) human immortalized non-tumorigenic keratinocytes cell line $\mathrm{HaCaT}$, acquired from CLS Cell Lines Service, Germany; and (iv) human foreskin fibroblasts (HFF-1), purchased from ATCC (ATCC Number SCRC-1041; ATCC, Manassas, VA, USA). Passage 81-84, 35-38, 21-23, and 83-85 from Caco-2, MTX-HT29, HaCaT and HFF-1 were, respectively, used for the MTT assay. Cells were grown according to the methodology described by de Francisco et al. [32].

\subsection{Statistical Analysis}

Results were presented as mean \pm standard deviation of at least triplicate experiments. Design Expert trial version 7 (Stat-Ease Inc., Minneapolis, MN, USA) was used to the determination of the regression equations, analysis of the response surface and contour plots, and statistical analysis of the experimental design. IBM SPSS Statistics 24.0 software (SPSS Inc., Chicago, IL, USA) was used to perform the analysis of the data. One-way ANOVA was applied to investigate the differences between samples for all assays and post hoc comparisons were performed with Tukey's HSD test. A denoting significance was accepted for $p<0.05$ in all cases. A correlation study was also performed, being selected the Pearson's correlation coefficient ' ${ }^{\prime}$ '. In ROS and RNS assays, the GraphPad Prism 7 software (GraphPad, La Jolla, CA, USA) was used to calculate the $\mathrm{IC}_{50}$ values based on the curves of inhibition percentage versus antioxidant concentration.

\section{Results and Discussion}

The extractive process is an essential step in the recovery and purification of bioactive compounds (such as phenolic compounds) from plant matrices [33]. The extraction efficiency depends on several parameters, such as temperature, time, solvent polarity, $\mathrm{pH}$, among others [34]. The RSM is a useful statistical toll for assessing the effect and interaction of many of these variables and finding the variables combinations that will produce the optimal response [35]. In this work, the variables under study were temperature and time; UAE experimental conditions, as well as the predicted and experimental values of TPC, FRAP, DPPH and ABTS assays of $C$. sativa shell extracts are presented in Table 1. The yield value of each extraction is also shown in Table 1, ranging from $7.3 \%$ (extraction $1,40{ }^{\circ} \mathrm{C}, 10 \mathrm{~min}$ ) to $16.1 \%$ (extraction $4,70{ }^{\circ} \mathrm{C}, 40 \mathrm{~min}$ ). Regarding the evaluated activities of the extracts, TPC ranged from $255.8 \mathrm{mg} \mathrm{GAE} / \mathrm{g} \mathrm{dw}$ (extraction $5,55^{\circ} \mathrm{C}, 4 \mathrm{~min}$ ) to $418.0 \mathrm{mg} \mathrm{GAE} / \mathrm{g} \mathrm{dw}$ (extraction $7,34{ }^{\circ} \mathrm{C}$, $25 \mathrm{~min}$ ); FRAP varied between $28.7 \mu \mathrm{g} / \mathrm{mL}$ (extraction $7,34^{\circ} \mathrm{C}, 25 \mathrm{~min}$ ) and $45.3 \mu \mathrm{g} / \mathrm{mL}$ (extraction 5 , 
$55^{\circ} \mathrm{C}, 4 \mathrm{~min}$ ); DPPH ranged from $43.7 \mu \mathrm{g} / \mathrm{mL}$ (extraction $7,34{ }^{\circ} \mathrm{C}, 25 \mathrm{~min}$ ) to $63.7 \mu \mathrm{g} / \mathrm{mL}$ (extraction 5 , $55^{\circ} \mathrm{C}, 4 \mathrm{~min}$ ); ABTS ranged from $50.5 \mu \mathrm{g} / \mathrm{mL}$ (extraction $5,55^{\circ} \mathrm{C}, 4 \mathrm{~min}$ ) to $88.0 \mu \mathrm{g} / \mathrm{mL}$ (extraction 12 , $55^{\circ} \mathrm{C}, 25 \mathrm{~min}$ ). The results of variance analysis (ANOVA) allow the evaluation of the adequacy and significance of the models through Fisher's $F$ test and are presented in Table 2.

The independent variable $X_{1}$ showed a significant effect on the TPC $(p<0.01)$ and FRAP $(p<0.05)$ response, while the independent variable $X_{2}$ had no significant effect on any response. The quadratic term for $X_{1}$ exhibited a significant effect on TPC $\left(Y_{1}\right)$ and antioxidant activity through FRAP $\left(Y_{2}\right)$ and ABTS $\left(Y_{4}\right)$ assays, while the quadratic term for $X_{2}$ showed a significant effect on FRAP $\left(Y_{2}\right)$ and ABTS $\left(Y_{4}\right)$ responses. The $R^{2}$ is useful to verify the adequacy of the model. The values showed that the models explained $84.90 \%, 85.42 \%, 75.74 \%$, and $74.76 \%$ of the variation of $X_{1}$ and $X_{2}$ for the respective TPC, FRAP, DPPH, and ABTS responses (Table 2). For all response surface models, the "lack of fit" was not significant $(p>0.05)$ and the Ratio was greater than 4 (as desired), indicating an adequate signal to noise ratio. All these indicators confirmed the adequacy of the model to represent the experimental data and to predict the four parameters analyzed. Response Equations (1)-(4) show the dependence of TPC $\left(Y_{1}\right)$, FRAP $\left(Y_{2}\right), \operatorname{DPPH}\left(Y_{3}\right)$, and ABTS $\left(Y_{4}\right)$ on time $\left(X_{1}\right)$ and temperature $\left(X_{2}\right)$ and were determined by regression analysis:

$$
\begin{gathered}
\mathrm{TPC}=456.89+9.00 x X_{1}-9.23 x X_{2}-0.02 x X_{1} x X_{2}-0.12 x X_{1}^{2}+0.09 X_{2}^{2} \\
\text { FRAP }=6.81-0.66 x X_{1}+1.50 x X_{2}-0.001 x X_{1} x X_{2}+0.01 x X_{1}^{2}-0.01 X_{2}^{2} \\
\text { DPPH }=-27.68+0.42 x X_{1}-3.07 x X_{2}-0.02 x X_{1} x X_{2}+0.008 x X_{1}^{2}-0.02 X_{2}^{2} \\
\text { ABTS }=-43.59+2.78 x X_{1}-3.29 x X_{2}-0.002 x X_{1} x X_{2}-0.05 x X_{1}^{2}-0.03 X_{2}^{2}
\end{gathered}
$$

The RSM model was used to generate 3D contour graphs to represent the relationship between the independent variables (time and temperature) and the dependent variables (ABTS, FRAP, DPPH and TPC). Figure 1 shows the response surface graphs of antioxidant activity assessed by three assays (ABTS, DPPH and FRAP), as well as TPC as a function of time and extraction temperature. 
Table 2. Model summary and analysis of variance (ANOVA) of TPC (mg GAE/g dw), FRAP (IC $50 \mu \mathrm{g} / \mathrm{mL}$ ), DPPH (IC $50 \mu \mathrm{g} / \mathrm{mL}$ ) and ABTS (IC $50 \mu \mathrm{g} / \mathrm{mL}$ ) of $\mathrm{C}$. sativa shells extracts.

\begin{tabular}{|c|c|c|c|c|c|c|c|c|c|c|c|c|c|c|c|c|}
\hline & \multicolumn{4}{|c|}{ Sum of Squares } & \multicolumn{4}{|c|}{ Mean Squares } & \multicolumn{4}{|c|}{$F$ Value } & \multicolumn{4}{|c|}{$p$-Value } \\
\hline & $Y_{1}$ & $Y_{2}$ & $Y_{3}$ & $Y_{4}$ & $Y_{1}$ & $Y_{2}$ & $Y_{3}$ & $Y_{4}$ & $Y_{1}$ & $Y_{2}$ & $Y_{3}$ & $Y_{4}$ & $Y_{1}$ & $Y_{2}$ & $Y_{3}$ & $Y_{4}$ \\
\hline Model & $16,263.02$ & 181.32 & 389.76 & 1144.33 & 3252.60 & 36.26 & 77.95 & 228.87 & 7.87 & 8.20 & 4.37 & 4.15 & $0.0086 *$ & $0.0077^{*}$ & $0.0399 * *$ & $0.0452 * *$ \\
\hline $\mathrm{X}_{1} \min$ & 5909.92 & 52.97 & 50.20 & 22.17 & 5909.92 & 52.97 & 50.20 & 22.17 & 14.30 & 11.98 & 2.81 & 0.40 & $0.0069 *$ & $0.0105^{* *}$ & 0.1373 & 0.5464 \\
\hline $\mathrm{X}_{2}{ }^{\circ} \mathrm{C}$ & 753.57 & 4.01 & 16.66 & 15.37 & 753.57 & 4.01 & 16.66 & 15.37 & 1.82 & 0.91 & 0.93 & 0.28 & 0.2190 & 0.3725 & 0.3661 & 0.6141 \\
\hline$x_{1} \cdot x_{2}$ & 87.32 & 0.15 & 63.38 & 1.21 & 87.32 & 0.15 & 63.38 & 1.21 & 0.21 & 0.03 & 3.55 & 0.02 & 0.6597 & 0.8611 & 0.1014 & 0.8865 \\
\hline $\mathrm{X}_{1} \cdot \mathrm{x}_{1}$ & 5152.91 & 40.68 & 21.38 & 905.69 & 5152.91 & 40.68 & 21.38 & 905.69 & 12.47 & 9.20 & 1.20 & 16.41 & 0.0096 * & $0.0190 * *$ & 0.3098 & 0.0049 * \\
\hline$x_{2} \cdot x_{2}$ & 3146.96 & 67.71 & 216.01 & 321.95 & 3146.96 & 67.71 & 216.01 & 321.95 & 7.61 & 15.31 & 12.11 & 5.83 & 0.0281 & $0.0058^{*}$ & 0.0103 & $0.0464^{*}$ \\
\hline Residual & 2893.59 & 30.95 & 124.86 & 386.38 & 413.37 & 4.42 & 17.84 & 55.20 & & & & & & & & \\
\hline Lack of fit & 2336.95 & 20.87 & 55.47 & 133.42 & 778.98 & 6.96 & 18.49 & 44.47 & 5.60 & 2.76 & 1.07 & 0.70 & 0.0648 & 0.1757 & 0.4571 & 0.5978 \\
\hline Pure error & 556.64 & 10.08 & 69.40 & 252.96 & 139.16 & 2.52 & 17.35 & 63.24 & & & & & & & & \\
\hline Total & $19,156.61$ & 212.27 & 514.63 & 1530.71 & & & & & & & & & & & & \\
\hline
\end{tabular}

$R^{2} \overline{\operatorname{prev}}\left(Y_{1}\right)=0.8490 ; R^{2}$ adj $\left(Y_{1}\right)=0.7411 ;$ Ratio $=10.80 ; R^{2} \operatorname{prev}\left(Y_{2}\right)=0.8542 ; R^{2}$ adj $\left(Y_{2}\right)=0.7500 ;$ Ratio $=11.00 ; R^{2}$ prev $\left(Y_{3}\right)=0.7574 ; R^{2}$ adj $\left(Y_{3}\right)=0.5841 ; \operatorname{Ratio}=7.05 ; R^{2}$ prev $\left(Y_{4}\right)=0.7476 ;$

$R^{2}$ adj $\left(Y_{4}\right)=0.5673 ;$ Ratio $=4.99 ; R^{2}$ prev $\left(Y_{4}\right)=0.7476 ; R^{2}$ adj $\left(Y_{4}\right)=0.5673 ;$ Ratio $=4.99$. ${ }^{*}$ significance at $p<0.01 ;{ }^{* *}$ significance at $p<0.05$. 
(A)
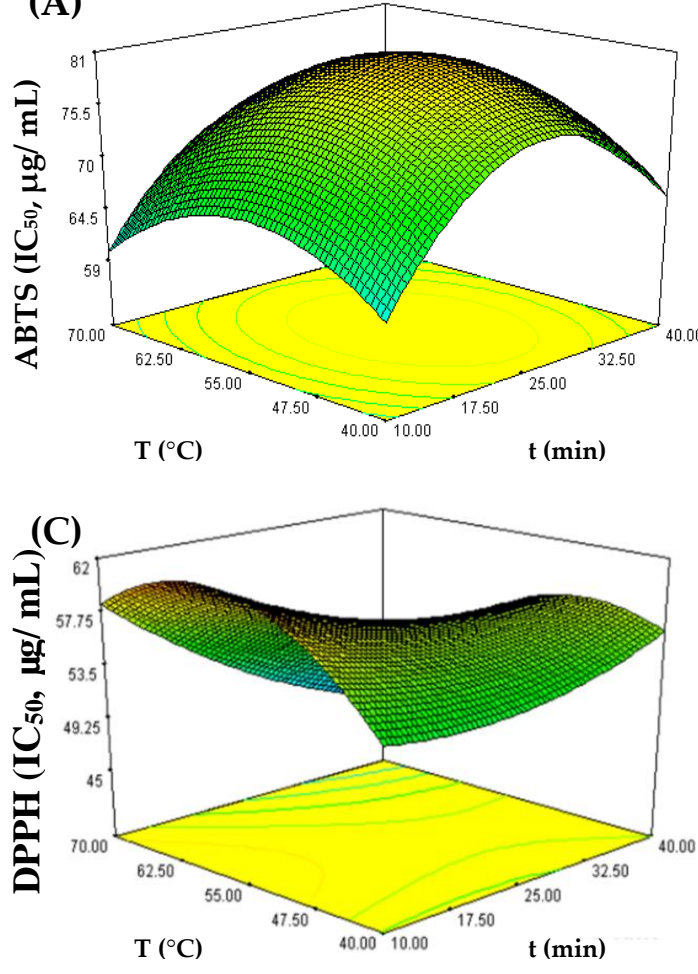

(B)
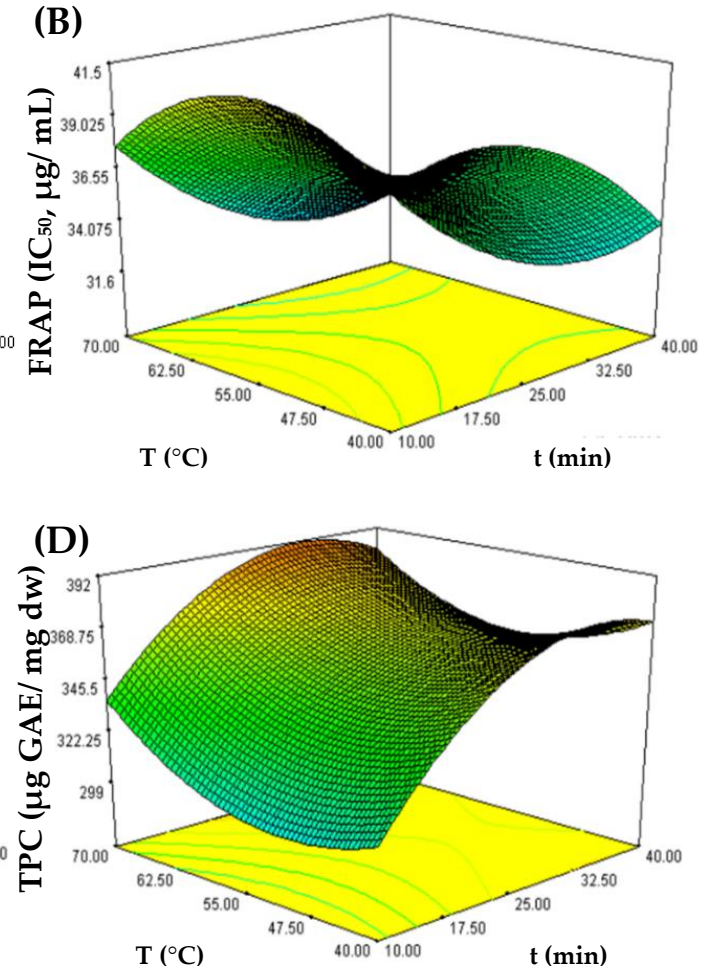

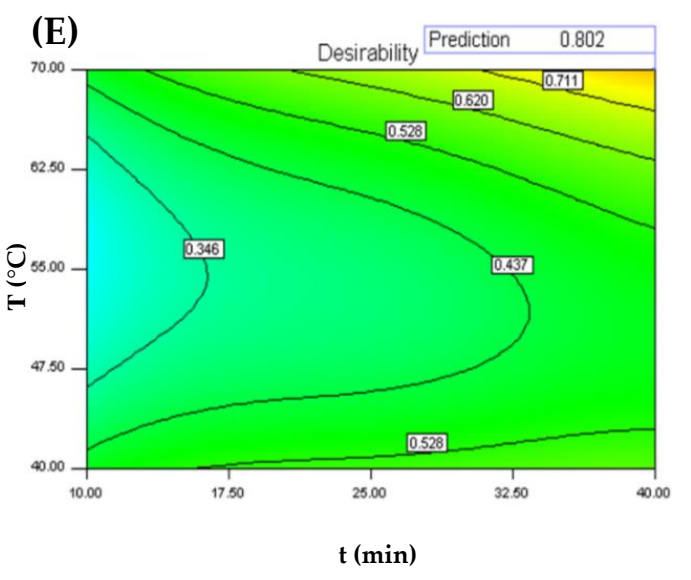

Figure 1. Response surface plots for interaction effects of time (min) and temperature on ABTS (A), FRAP (B), DPPH (C), and TPC (D) extraction and on the desirability index for combined responses of UAE-CSS extracts (E). The optimal points were identified on the response surfaces.

As shown in Figure 1A-D, temperature and extraction time influence ABTS, DPPH, FRAP and TPC assay responses, respectively. However, the TPC response showed a distinct variation with respect to the antioxidant activity assessed by ABTS, DPPH, and FRAP assays. Effectively, a higher antioxidant activity was found (DPPH $=45.5 \mu \mathrm{g} / \mathrm{mL} ;$ ABTS $=59.9 \mu \mathrm{g} / \mathrm{mL} ; \mathrm{FRAP}=31.7 \mu \mathrm{g} / \mathrm{mL}$ ) when UAE conditions were $70^{\circ} \mathrm{C}$ and, respectively, 40, 10, and $34 \mathrm{~min}$, suggesting that under these extraction conditions more compounds with higher antioxidant activity are extracted or probably formed. The desirability for these assays was greater than 0.7492 . In contrast, there was a decrease in the antioxidant activity when the extraction temperature was $55^{\circ} \mathrm{C}$. In the case of the TPC, it is possible to observe an increase in polyphenol content as the temperature and extraction time increased, reaching a maximum response (391.6 $\mathrm{mg} \mathrm{GAE} / \mathrm{g} \mathrm{dw}$ ) at the extractive conditions of $70{ }^{\circ} \mathrm{C}$ and $31 \mathrm{~min}$; the desirability was 0.8925. These results are in line with Gironi and Piemonte [36], who reported that the use of high temperatures $\left(50-80^{\circ} \mathrm{C}\right)$ increases the extraction of bioactive compounds from plant matrices. 
According to the desirability graph (Figure 1E), optimal UAE conditions to simultaneously maximize antioxidant activity and TPC were $40 \mathrm{~min}$ at $70{ }^{\circ} \mathrm{C}\left(R^{2}=0.8024\right)$. As shown in Table 3 , the experimental value for the four responses was similar to the value predicted by the model $(p<0.05)$, showing once again the effectiveness of RSM for the optimization of antioxidant compounds and polyphenols extraction from chestnut shells using UAE.

Table 3. TPC and antioxidant activity evaluated by TPC, DPPH, ABTS and FRAP assays of the optimal extract of $C$. sativa shells $\left(70{ }^{\circ} \mathrm{C} / 40 \mathrm{~min}\right)$.

\begin{tabular}{|c|c|c|c|c|}
\hline & $\begin{array}{c}\text { TPC } \\
\text { (mg GAE/g dw) }\end{array}$ & $\begin{array}{c}\text { DPPH } \\
\left(\mathrm{IC}_{50} ; \mu \mathrm{g} / \mathrm{mL}\right)\end{array}$ & $\begin{array}{c}\text { ABTS } \\
\left(\mathrm{IC}_{50} ; \mu \mathrm{g} / \mathrm{mL}\right)\end{array}$ & $\begin{array}{c}\text { FRAP } \\
\left(\mathrm{IC}_{50} ; \mu \mathrm{g} / \mathrm{mL}\right)\end{array}$ \\
\hline Experimental value $^{a}$ & $393.1 \pm 14.0$ & $44.1 \pm 3.4$ & $65.4 \pm 3.5$ & $32.0 \pm 1.5$ \\
\hline Predicted value & 382.3 & 45.5 & 62.1 & 32.1 \\
\hline$p^{b}$ & 0.066 & 0.414 & 0.226 & 0.499 \\
\hline
\end{tabular}

$\mathrm{IC}_{50}=$ In vitro concentration required to decrease in $50 \%$ the reactivity of the studied reactive species in the tested media (mean \pm standard error of the mean). ${ }^{a}$ Results are expressed as mean \pm standard deviation $(n=3) .{ }^{b}$ indicates significant differences $(p<0.05)$.

Generally, extracts containing high amounts of polyphenols also exhibit high antioxidant activity [37]. According to Table 3, the TPC was $393.1 \mathrm{mg} \mathrm{GAE} / \mathrm{g} \mathrm{dw}$. Previously, Barreira et al. evaluated the antioxidant properties of $C$. sativa shell extract using water at $100{ }^{\circ} \mathrm{C}$ for $30 \mathrm{~min}$ as extraction solvent (with a solid/liquid ratio of $5 \mathrm{~g} / 50 \mathrm{~mL}$ ) [38]. The TPC determined for outer and inner shells were, respectively, 510 and $475 \mathrm{mg} \mathrm{GAE} / \mathrm{g} \mathrm{dw}$, being higher than the TPC of the present study. These differences could be explained by the use of a higher solid/liquid ratio $(5 \mathrm{~g} / 50 \mathrm{~mL})$ [38]. In another study, Nazzaro et al. evaluated the TPC of $C$. sativa shells using water at room temperature as extraction solvent during 5 days [39]. The TPC verified was $333.2 \mathrm{mg} \mathrm{GAE} / \mathrm{g} \mathrm{dw}$ [39]. According to Squillaci et al., C. sativa shells extract, when subjected to water extraction at $100{ }^{\circ} \mathrm{C}$ for $60 \mathrm{~min}$, contains a high content of phenolic compounds (206 mg GAE/g dw) [1]. This value, obtained by a conventional technique using a similar solid/liquid ratio $(5 \mathrm{~g} / 100 \mathrm{~mL})$, is lower than the one obtained in the present study. Rodrigues et al. evaluated the TPC of $C$. sativa shell (extracted with ethanol: water (1:1) at $50{ }^{\circ} \mathrm{C}$ for $30 \mathrm{~min}$ (with a solid/liquid ratio of $5 \mathrm{~g} / 100 \mathrm{~mL}$ ) using a conventional technique [40]. The results obtained ranged from 241.9 to $796.8 \mathrm{GAE} / \mathrm{g} \mathrm{dw}$ for the Portuguese regions of Minho and Trás os-Montes, respectively [40]. Comparing the value obtained in the present study ( $393.1 \mathrm{mg} \mathrm{GAE} / \mathrm{g}$ $\mathrm{dw}$ ) with the values reported by different authors for the same by-product, it is possible to conclude that UAE not only improved the extraction time but also decreased the temperature used, allowing to obtain similar and higher results.

According to Table 3, the $\mathrm{IC}_{50}$ determined for the DPPH assay was $44.1 \mu \mathrm{g} / \mathrm{mL}$, being higher than the antioxidant activity obtained for Trolox $\left(\mathrm{IC}_{50}=51.6 \mu \mathrm{g} / \mathrm{mL}\right)$. Almeida et al. reported an $\mathrm{IC}_{50}=17.7 \mu \mathrm{g} / \mathrm{mL}$ for $C$. sativa leaves extracted with water (during $20 \mathrm{~min}$ at $40^{\circ} \mathrm{C}$ and $500 \mathrm{rpm}$ ) [41]. Similarly, Pinto et al. determined the antioxidant activity of hydroalcoholic extracts of $C$. sativa burs from different regions of Portugal (prepared at $40{ }^{\circ} \mathrm{C}$ during $30 \mathrm{~min}$ ), achieving a slightly higher $\mathrm{DPPH} \bullet$ scavenging ability $\left(\mathrm{IC}_{50}=38.7 \mu \mathrm{g} / \mathrm{mL}\right)$ for Minho samples [42]. In fact, polyphenols are secondary metabolites that perform a key role in the defense and survival of plants, having important functions in their adaptation to biotic and abiotic conditions [43,44]. In this sense, plants produce polyphenols as a defense mechanism against the attacks on plant tissues or in a stressful environment (e.g., unfavorable temperature, light and $\mathrm{pH}$ conditions) [44]. The environmental conditions, namely light, soil nutrients, temperature or water availability can effectively influence the phenolic composition and concentration in plants and its derivatives [43]. Also, the type and concentration of polyphenols varies depending on the plant tissue and its stage of development [43]. The high antioxidant activity of chestnut shells and leaves extracts obtained at lower temperatures is probably related to the high amount of polyphenols as a consequence of the exposure to stress conditions, initiating the plants' defense mechanism $[40,42,43]$. Comparing the results obtained with those reported for walnut shells 
$\left(\mathrm{IC}_{50}=0.35 \mathrm{mg} / \mathrm{mL}\right)$, hazelnut skins $\left(\mathrm{IC}_{50}=1.0 \mathrm{mg} / \mathrm{mL}\right)$ and almond shells $\left(\mathrm{IC}_{50}=193.6 \mu \mathrm{g} / \mathrm{mL}\right)$, the antioxidant activity is considerably higher [45-47].

According to Table 3 , the $\mathrm{IC}_{50}$ determined for the ABTS assay was $65.4 \mu \mathrm{g} / \mathrm{mL}$ while for ascorbic acid (data not shown in the table), used as reference, an $\mathrm{IC}_{50}=42.0 \mu \mathrm{g} / \mathrm{mL}$ was achieved. Fernández-Agulló et al. analyzed the antioxidant activity of $C$. sativa shells and burs extracted using conventional methodologies, with different solvents, at $75{ }^{\circ} \mathrm{C}$ during 60 to $120 \mathrm{~min}$ [48]. According to the authors, the $\mathrm{IC}_{50}$ determined for the ABTS assay on chestnut shells was $0.3 \mathrm{mg} / \mathrm{mL}$ (using water as a solvent), while for bur the result was $0.5 \mathrm{mg} / \mathrm{mL}$ (with water: ethanol (1:1)) [48]. Thus, the antioxidant activity determined in the present study is higher.

Finally, an $\mathrm{IC}_{50}=32.0 \mu \mathrm{g} / \mathrm{mL}$ was obtained for the FRAP assay. Dinis et al. analyzed the antioxidant activity of chestnut from different ecotypes of the Trás-os-Montes region (Portugal) extracted with 50\% ethanol during $1 \mathrm{~h}$ [49]. The $\mathrm{IC}_{50}$ ranged between $6.6 \mu \mathrm{g} / \mathrm{mL}$ and $14.6 \mu \mathrm{g} / \mathrm{mL}$, being the antioxidant activity higher than the one obtained in the present study, which could be explained by weather conditions and extraction solvents used [49]. However, when the comparison is made with other food by-products, such as $Q$. cerris seeds $\left(\mathrm{IC}_{50}=203.1 \mu \mathrm{g} / \mathrm{mL}\right.$ ) or olive leaves $\left(\mathrm{IC}_{50}=180 \mu \mathrm{g} / \mathrm{mL}\right.$ ), the chestnut shell presented a higher antioxidant activity [50,51].

Overall, the high antioxidant activity of extracts, proved by ABTS, DPPH and FRAP assays, is probably related with the TPC. Therefore, it is possible to conclude that UAE allowed a high recovery of polyphenols with remarkable antioxidant properties, reducing the extraction time and ensuring low environmental impacts. In particular, most of the studies about chestnut shells used high temperatures and/or long extraction times for polyphenols recovery, which comprises a disadvantage to an industrial application since the extraction process becomes more expensive and increases the manufacturing costs $[1,38,48]$. In addition, water was efficiently used in the present study as a green and cheaper solvent, in contrast with previous studies cited that employed ethanol $[40,48,49]$.

\subsection{ROS and RNS Scavenging Assays}

Reactive species are one of the main causes of oxidative stress, being responsible for the aging process [35,52]. The overproduction of ROS may have negative impact on essential cells molecules, including lipids, proteins and DNA. However, due to their antioxidant capacity and radical scavenging activity, phenolic compounds may attenuate the effects of this process, preventing the biochemical consequences of oxidation [30,35]. Table 4 summarizes the in vitro scavenging capacity of $C$. sativa shells extract and the positive controls used.

Table 4. Superoxide anion radical $\left(\mathrm{O}_{2} \bullet^{-}\right)$, hypochlorous acid $(\mathrm{HOCl})$, peroxyl radical $(\mathrm{ROO} \bullet)$ and nitric oxide $\left(\mathrm{NO} \bullet^{-}\right)$scavenging capacities of optimal $C$. sativa shells extract. Values are expressed as mean \pm standard deviation $(n=4)$.

\begin{tabular}{|c|c|c|c|c|}
\hline & \multicolumn{3}{|r|}{ ROS } & \multirow{3}{*}{$\begin{array}{c}\text { RNS } \\
\mathrm{IC}_{50}(\mu \mathrm{g} / \mathrm{mL}) \\
\mathrm{NO}^{-}{ }^{-}\end{array}$} \\
\hline & \multicolumn{2}{|c|}{$\mathrm{IC}_{50}(\mu \mathrm{g} / \mathrm{mL})$} & \multirow{2}{*}{$\begin{array}{c}\text { Trolox Equivalents }(\mu \mathrm{mol} \mathrm{TE} / \mathrm{mg} \mathrm{dw}) \\
\text { ROO• }\end{array}$} & \\
\hline & $\mathrm{O}_{2} \bullet^{-}$ & $\mathrm{HOCl}$ & & \\
\hline C. sativa shell extract & $14.1 \pm 0.5$ & $0.7 \pm 0.0$ & $0.3 \pm 0.0$ & $0.1 \pm 0.0$ \\
\hline \multicolumn{5}{|l|}{ Positive controls } \\
\hline Gallic acid & $5.2 \pm 0.3$ & $1.3 \pm 0.1$ & $6.0 \pm 0.2$ & $0.2 \pm 0.0$ \\
\hline Catechin & $49.0 \pm 1.3$ & $0.2 \pm 0.0$ & $46.4 \pm 0.2$ & $1.0 \pm 0.0$ \\
\hline
\end{tabular}

$\mathrm{IC}_{50}=$ In vitro concentration required to decrease in $50 \%$ the reactivity of the studied reactive species in the tested media (mean \pm standard error of the mean).

Similarly to previous studies, different assays were employed to investigate the effectiveness of CSS extract to scavenge reactive species produced in human body (ROS and RNS) and to estimate its potential use as active ingredient with benefits in the prevention of oxidative stress-mediated disorders $[31,35,50]$. The scavenging capacity of extracts differs for each reactive species, which 
supports the need to measure this activity for different reactive species [31,32,50]. Among the ROS and RNS studied, the highest scavenging efficiencies of the optimal CSS extract were achieved for NO• $\left(\mathrm{IC}_{50}=0.1 \mu \mathrm{g} / \mathrm{mL}\right)$ and $\mathrm{HOCl}\left(\mathrm{IC}_{50}=0.7 \mu \mathrm{g} / \mathrm{mL}\right)$.

Superoxide radical formation is the first step for the generation of oxygen species, being considered the starting point of oxidative stress $[53,54]$. According to Table 4 , the optimal extract presented an $\mathrm{IC}_{50}=14.1 \mu \mathrm{g} / \mathrm{mL}$ for the scavenging of this species, being lower than the result obtained for catechin $\left(\mathrm{IC}_{50}=49.0 \mu \mathrm{g} / \mathrm{mL}\right)$. Almeida et al. and Reinoso et al. evaluated the protective effect of $C$. sativa leaves extract with respect to ROS uptake capacity, obtaining similar results for the superoxide radical (respectively an $\mathrm{IC}_{50}=13.6 \mu \mathrm{g} / \mathrm{mL}$ and $\mathrm{IC}_{50}=15.1 \mu \mathrm{g} / \mathrm{mL}$ ) [4,52].

In what concerns to the uptake of peroxyl radical, the result present in Table $4(0.3 \mu \mathrm{mol} \mathrm{TE} / \mathrm{mg}$ $\mathrm{dw})$ is lower than the ones reported by Almeida et al. $(1.2 \mu \mathrm{mol} \mathrm{TE} / \mathrm{mg} \mathrm{dw})$ and Reinoso et al. $(1.1 \mu \mathrm{mol}$ $\mathrm{TE} / \mathrm{mg} \mathrm{dw}$ ) for chestnut leaves [4,52]. To the best of our knowledge, this study reports for the first time the scavenging activity of chestnut shells against this reactive oxygen species.

Indeed, the optimal extract had a good scavenge capacity of hypochlorous acid, achieving a low $\mathrm{IC}_{50}(0.7 \mu \mathrm{g} / \mathrm{mL})$ that is between the two positive controls used, catechin $(0.2 \mu \mathrm{g} / \mathrm{mL})$ and gallic acid $(1.3 \mu \mathrm{g} / \mathrm{mL})$. In a recent study, Marangi et al. evaluated an aqueous extract of $A$. arguta leaves obtaining an $\mathrm{IC}_{50}=1.7 \mu \mathrm{g} / \mathrm{mL}$ [31]; the scavenging activity of this species was lower than the optimal extract developed in the present work. The scavenging power of the optimal extract against NO• $\left(\mathrm{IC}_{50}=0.1 \mu \mathrm{g} / \mathrm{mL}\right)$ was also higher than $C$. sativa leaves extract $\left(\mathrm{IC}_{50}=3.1 \mu \mathrm{g} / \mathrm{mL}\right.$ and $\mathrm{IC}_{50}=7.2 \mu \mathrm{g} / \mathrm{mL}$, respectively) [4,52]. In addition, a lower quenching ability was obtained for $A$. arguta leaves extract $\left(\mathrm{IC}_{50}=3.80 \mu \mathrm{g} / \mathrm{mL}\right)[31]$.

Considering the previous results, the optimal extract prepared by UAE showed promising results concerning the quenching ability against the ROS and RNS probably due to the phenolic composition. In particular, the presence of ellagic acid, catechin/epicatechin, epigallocatechin and a caffeic acid derivative, whose scavenging power has been described by several authors $[55,56]$, may contribute to this activity (Figure 2; Table 5).

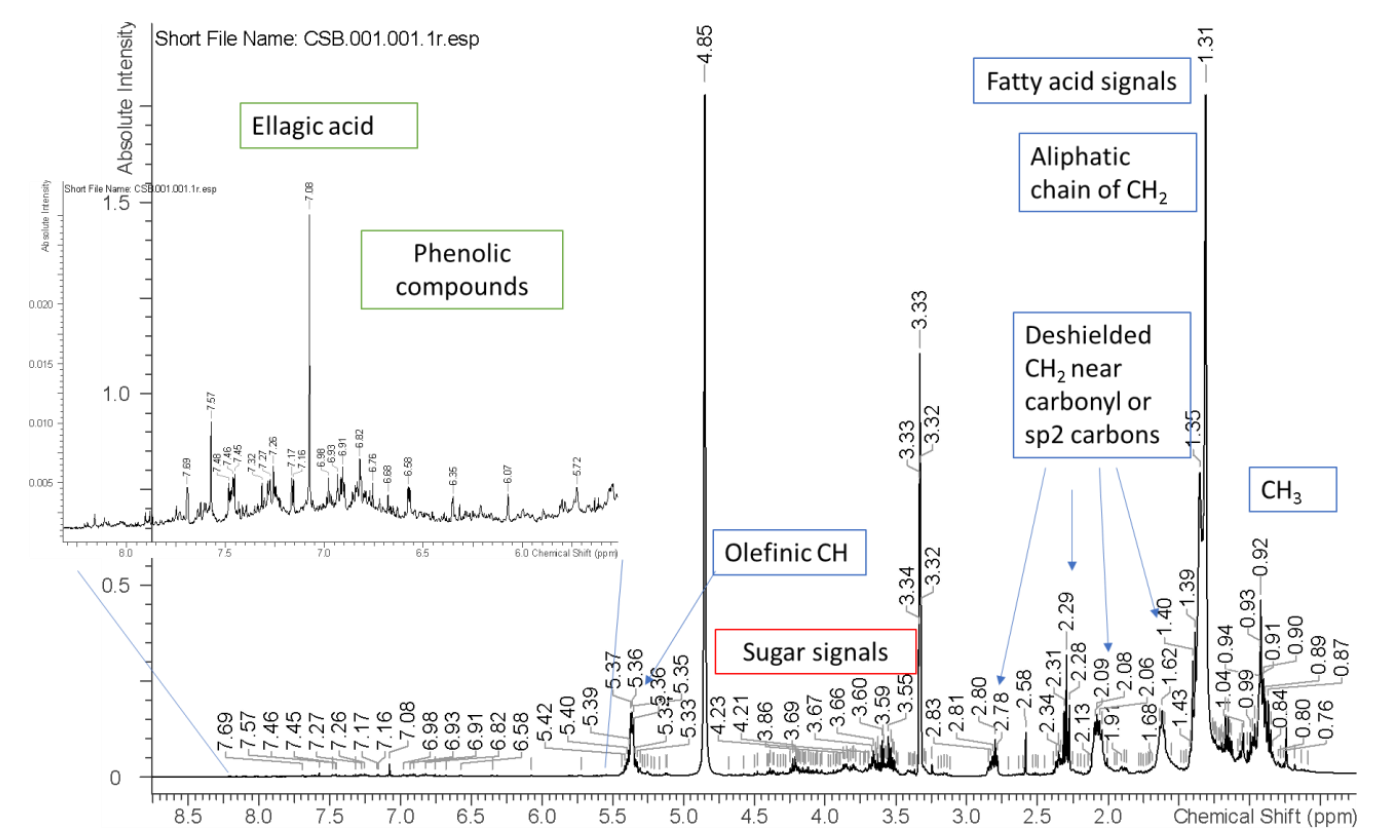

Figure 2. ${ }^{1} \mathrm{H}$ NMR of the optimal extract recorded in $\mathrm{D}_{2} \mathrm{O}$. 
Table 5. Identification and quantification of the phenolic compounds from the optimal extract by LC-MS analysis.

\begin{tabular}{cccccc}
\hline No. & Tr $(\mathbf{m i n})$ & {$[\mathbf{M}-\mathbf{H}]^{-}$} & Fragments & Identification & $\begin{array}{c}\text { Amount } \\
(\mu \mathbf{g} / \mathbf{m g} \mathbf{d w})\end{array}$ \\
\hline 1 & 10.5 & 289 & - & Catechin/epicatechin & $7.4 \pm 0.1$ \\
\hline 2 & 12.4 & 301 & $\begin{array}{c}2842572292213 \\
201185173\end{array}$ & Ellagic acid & $40.4 \pm 0.1$ \\
\hline 3 & 13.7 & 1153 & - & Tetrameric PAC & $1.0 \pm 0.1$ \\
\hline 4 & 14.0 & 305 & 179 & Epigallocatechin & $15.3 \pm 0.1$ \\
\hline 5 & 19.2 & 577 & 269 & Apigenin-7-O-rutinoside & $0.8 \pm 0.0$ \\
\hline 6 & 19.3 & 577 & - & Trimeric PAC & $4.2 \pm 0.1$ \\
\hline 7 & 20.2 & 593 & 285257241217199 & Luteolin-7-O-rutinoside & $1.1 \pm 0.1$ \\
\hline 8 & 22.6 & 589 & 175 & Trimeric PAC & $1.1 \pm 0.1$ \\
\hline 9 & 28.7 & 341 & 179161143 & Caffeic acid derivative & $15.4 \pm 0.1$ \\
\hline 10 & 45 & 1431 & - & Procyanidin polimers & $11.1 \pm 0.1$ \\
\hline
\end{tabular}

\section{2. ${ }^{1} H$ NMR and LC-MS Analysis}

The multi-technique approach ${ }^{1} \mathrm{H}$ NMR and liquid chromatography coupled with diode array, fluorescence and Mass spectrometry, were used to establish the phytochemical composition of the optimal extract. From ${ }^{1} \mathrm{H}$ NMR spectrum it is possible to observe characteristic signals of fatty acid derivatives, sugar residues and phenolic compounds. For these latter compounds, the significant signals were the singlet at $\delta 7.15 \mathrm{ppm}$ that appear to be correlated in the HSQC spectrum to an aromatic carbon resonance at $\delta 108.6 \mathrm{ppm}$, supporting the presence of ellagic acid derivatives. Furthermore, several signals in the aromatic part presenting not resolved peaks in the region of $\delta 6.7-6.0 \mathrm{ppm}$ and $6.5 \mathrm{ppm}$ suggest the presence of high polymeric phenolics as procyanidins and flavonols. Other signals are also present as singlets or doublets in the region of $\delta 5-5.5 \mathrm{ppm}$, indicating the presence of sugar, or ester linked $\mathrm{OCH}$ of sugars.

Further data were obtained using LC-DAD-ESI-MS ${ }^{\mathrm{n}}$ in the negative ionization mode (Table 5), showing a limited number of peaks with significant UV absorption and MS spectra. C-18 and HILIC separations were obtained. The most efficient separation was achieved on HILIC column and an exemplificative chromatogram is reported in Figure 2.

The results of $\mathrm{C}-18$ analysis allowed the identification of caffeic acid derivatives in the first part of the chromatogram and ellagic acid as main constituent. Other minor species were detected and showed significant mass spectra, but it was not possible to assess their tentative structure due to the low amount. The observation of the NMR spectra suggested the presence of low amounts of procyanidins.

According to Table 5, the most abundant compounds are ellagic acid $(40.4 \mu \mathrm{g} / \mathrm{mg})$, epigallocatechin $(15.3 \mu \mathrm{g} / \mathrm{mg})$ and caffeic acid derivative $(15.4 \mu \mathrm{g} / \mathrm{mg})$. These results are considerably higher than the ones reported by Aires et al. for chestnut peel extracts prepared by conventional extraction at $85^{\circ} \mathrm{C}$ using different solvents (water, $\mathrm{Na}_{2} \mathrm{SO}_{3}$ and $\mathrm{NaOH}$ at different concentrations of $1,2,4$, and $8 \%$ in water) and extraction times $(30,60$, and 120, 240, 480, and $960 \mathrm{~min}$ ) [12]. According to the authors, the major phenolic compounds were gallic acid $(7.9-584.9 \mu \mathrm{g} / \mathrm{g} \mathrm{dw})$, ellagic acid (47.6-3542.6 $\mu \mathrm{g} / \mathrm{g} \mathrm{dw})$, vescalagin

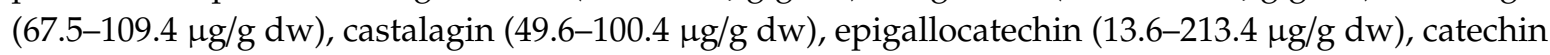
(151.1-295.9 $\mu \mathrm{g} / \mathrm{g} \mathrm{dw})$, and epicatechin $(9.0-66.8 \mu \mathrm{g} / \mathrm{g} \mathrm{dw})$. Ellagic acid $(3542.6 \mu \mathrm{g} / \mathrm{g} \mathrm{dw})$ was the major individual polyphenol quantified, being extracted with $1 \% \mathrm{NaOH}$ during $120 \mathrm{~min}$ [12]. Furthermore, the total amounts of polyphenols determined by Aires et al. ranged from 72.5 to $4033.3 \mu \mathrm{g} / \mathrm{g} \mathrm{dw}$, being significantly lower than the one obtained in the present study $(97.8 \mu \mathrm{g} / \mathrm{mg})$ [12]. A possible explanation for these differences might be the use of different extraction techniques as well as extraction conditions and solvents. 
On another study, Comandini et al. described the presence of gallic acid, ellagic acid, castalin, castalagin, 1-O-galloyl castalagin, vescalin, and vescalagin after extraction of chestnut bark at ambient temperature during $30 \mathrm{~min}$ and sonicated for $30 \mathrm{~min}$ in an ultrasonic bath operating at a frequency of $35 \mathrm{kHz}$ [57]. According to Squillaci et al., the aqueous extracts of the chestnut inner and outer shell, as well as the exclusive inner shell, contain a high content of phenolic compounds, with gallic acid being the most abundant $(63.5$ and $29.6 \mathrm{mg} / \mathrm{g} \mathrm{dw}$ for inner and outer shell extract and inner shell extract, respectively) [1].

\subsection{Cell Viability Studies}

In order to evaluate the possibility to use the optimal extract as new ingredient for different industries, cell viability studies were performed in intestinal (Caco-2 and HT29-MTX) and skin (HaCaT and HFF-1) cell lines. These cells are considered suitable in vitro models for testing the toxicity potential of substances or products intended for oral and dermatological use [58,59]. Caco-2 are morphological and functionally similar to enterocytes, while HT29-MTX are commonly employed for digestion and bioavailability studies of food compounds [60]. The results of the cell viability assay are summarized in Table 6.

Table 6. Effects of optimal extract exposure on the viability of Caco-2, HT29-MTX, HaCaT, and HFF-1 cells at different concentrations, as measured by the MTT assay.

\begin{tabular}{ccccc}
\hline & \multicolumn{4}{c}{ Cell Lines } \\
\hline Concentration $(\mu \mathrm{g} / \mathrm{mL})$ & Caco-2 & HT29-MTX & HaCaT & HFF-1 \\
\hline Medium & $100.0 \pm 14.5$ & $100.0 \pm 18.8$ & $101.0 \pm 3.4$ & $100.0 \pm 18.0$ \\
Triton X-100 & $0.0 \pm 0.0$ & $0.0 \pm 0.0^{\mathrm{a}}$ & $0.0 \pm 1.0$ & $0.0 \pm 4.1$ \\
0.1 & $68.8 \pm 10.2$ & $67.0 \pm 10.4^{\mathrm{a}, \mathrm{b}}$ & $97.8 \pm 17.8^{\mathrm{a}}$ & $105.6 \pm 1.6$ \\
1 & $55.6 \pm 6.1$ & $74.0 \pm 14.3^{\mathrm{a}}$ & $79.1 \pm 14.6^{\mathrm{b}}$ & $98.0 \pm 18.3$ \\
10 & $66.3 \pm 3.1$ & $35.5 \pm 6.7^{\mathrm{c}}$ & $77.0 \pm 9.6^{\mathrm{b}}$ & $117.2 \pm 20.8$ \\
100 & $79.2 \pm 15.5$ & $43.9 \pm 3.8^{\mathrm{b}, \mathrm{c}}$ & $80.4 \pm 10.7^{\mathrm{b}}$ & $118.0 \pm 5.8$ \\
1000 & $70.4 \pm 5.7$ & $65.3 \pm 1.0^{\mathrm{a}, \mathrm{b}}$ & $68.0 \pm 7.0^{\mathrm{b}}$ & $87.7 \pm 7.7$ \\
\hline
\end{tabular}

Values are expressed as mean \pm standard deviation $(n=4)$. Different letters $(a, b, c)$ in the same cell line represent significant differences $(p<0.05)$ between different concentrations of extract, according to Tukey's HSD test.

According to the results shown in Table 6, C. sativa extract obtained by UAE did not cause a decrease in keratinocytes viability at a concentration of $0.1 \mu \mathrm{g} / \mathrm{mL}$. However, at concentrations of 1,10 , and $100 \mu \mathrm{g} / \mathrm{mL}$, cell viability was respectively $79.1 \%, 77.0 \%$, and $80.4 \%$, while at the concentration of $1000 \mu \mathrm{g} / \mathrm{mL}$ the cell viability was $68.0 \%$. In this way, only the concentration of $0.1 \mu \mathrm{g} / \mathrm{mL}$ did not affect the cell viability.

Pinto et al. evaluated the effect on keratinocytes viability after exposure to chestnut bur extract obtained by maceration with a hydroalcoholic mixture at $40{ }^{\circ} \mathrm{C}$ for $30 \mathrm{~min}$ [61]. According to the authors, the extract did not decrease the cell viability between 0.1 and $100 \mu \mathrm{g} / \mathrm{mL}$. Nevertheless, at a concentration of $1000 \mu \mathrm{g} / \mathrm{mL}$, the cell viability decreased to $57.1 \%$, which is in line with the present results [61]. More recently, Squillaci et al. studied the effect on keratinocytes viability after exposure to an aqueous extract of chestnut shells (in concentrations between $0.0004 \%$ and $0.5 \%$ ) prepared in boiling water for $1 \mathrm{~h}$, reporting that the extract below $0.01 \%$ has no significant toxic effect [1].

Regarding fibroblasts viability, for all tested concentrations the viability is $100 \%$, without significant differences $(p>0.05)$ between concentrations. According to the literature, this is the first time that the effect of chestnut extracts in fibroblasts is reported.

In what concerns to intestinal cell lines, after exposure to the tested concentrations, both lines did not achieve a viability of $100 \%$. Once again, to the best of our knowledge, this is the first time that the effects on intestinal cell lines after exposure to chestnut shells extract is reported. Recently, Cacciola et al. exposed six tumor cell lines (DU 145, PC-3, LNCaP, MDA-MB-231, MCF-7, and HepG2) and one normal prostate epithelial cell line (PNT2) to different concentrations of aqueous chestnut shells extract 
(1-100 $\mu \mathrm{g} / \mathrm{mL}$ ) [62]. The authors reported a decrease on cell viability for less than 50\% (DU 145, LNCaP, and PNT2 cells) at the maximum concentration tested $(100 \mu \mathrm{g} / \mathrm{mL})$, which is in line with this study [62].

\section{Conclusions}

In this study, ultrasonic assisted technology was used for the extraction of phenolics and antioxidants from chestnut shells. The RSM was employed to optimize the independent variables, namely ultrasonic extraction temperature $\left({ }^{\circ} \mathrm{C}\right)$ and extraction time (min). The optimal conditions that maximized the amount of phenolics and antioxidant activity of CSS extracts were determined as follows: $70{ }^{\circ} \mathrm{C}$ of temperature and $40 \mathrm{~min}$ of extraction time. The efficiency of ultrasound-assisted extraction was strongly influenced by the extraction variables, indicating that chestnut shells are a good source of important antioxidants. Under the optimal conditions, the extraction yield was $16 \%$; the optimal extract showed a high content of phenolic compounds (393.1 mg GAE/g dw) as well as a high antioxidant activity ((DPPH, IC I0 $_{5}=44.1 \mu \mathrm{g} / \mathrm{mL}$; FRAP, IC $\mathrm{IC}_{50}=32.0 \mu \mathrm{g} / \mathrm{mL} ;$ ABTS, $\left.\mathrm{IC}_{50}=65.4 \mu \mathrm{g} / \mathrm{mL}\right)$. Indeed, a good scavenging capacity of $\mathrm{O}_{2} \bullet^{-}\left(\mathrm{IC}_{50}=14.1 \mu \mathrm{g} / \mathrm{mL}\right), \mathrm{HOCl}\left(\mathrm{IC}_{50}=0.7 \mu \mathrm{g} / \mathrm{mL}\right), \mathrm{NO} \bullet$ $\left(\mathrm{IC}_{50}=0.1 \mu \mathrm{g} / \mathrm{mL}\right)$ and ROO• (0.1) was observed. In what concerns to the bioactive compounds present, ellagic acid is the major one $(40.4 \mu \mathrm{g} / \mathrm{mg})$, followed by caffeic acid derivative $(15.4 \mu \mathrm{g} / \mathrm{mg})$ and epigallocatechin $(15.3 \mu \mathrm{g} / \mathrm{mg})$. The effect on skin and intestinal cell lines at different extract concentrations was also assessed by an MTT assay. According to the results obtained, there was no decrease in fibroblasts viability up to the maximum concentration tested $(1000 \mu \mathrm{g} / \mathrm{mL})$, while for keratinocytes the extract showed no adverse effects on the minimum concentration tested $(0.1 \mu \mathrm{g} / \mathrm{mL})$. The viability in intestinal cell lines did not achieved $100 \%$ for all tested concentrations. This study suggests for the first time the employment of UAE to extract bioactive compounds from CSS for different applications.

Author Contributions: Conceptualization, F.R. and C.D.-M.; methodology, F.L., D.P., A.F.P., C.F., F.R. and S.S.; software, E.F.V. and F.R.; validation, E.F.V., F.R. and P.C.; formal analysis, D.P., F.L., S.S., S.D., F.R.; investigation, F.L., D.P., P.C., F.R.; resources, C.D.-M. and F.R.; data curation, F.R., P.C and S.D.; writing-original draft preparation, F.L., D.P. and F.R.; writing-review and editing, F.R.; visualization, C.D.-M.; supervision, F.R.; project administration, F.R.; funding acquisition, F.R. All authors have read and agreed to the published version of the manuscript.

Funding: The authors are grateful to Sortegel for the samples. This work received financial support from project PTDC/ASP-AGR/29277/2017-Castanea sativa shells as a new source of active ingredients for Functional Food and Cosmetic applications: A sustainable approach, supported by national funds by FCT/MCTES and co-supported by Fundo Europeu de Desenvolvimento Regional (FEDER) throughout COMPETE 2020—Programa Operacional Competitividade e Internacionalização (POCI-01-0145-FEDER-029277). The work was also supported by UID/QUI/50006/2020 with funding from FCT/MCTES through national funds and by the Applied Molecular Biosciences Unit-UCIBIO, which is financed by national funds from FCT/MCTES (UID/Multi/04378/2020).

Acknowledgments: Diana Pinto is thankful for the PhD grant (SFRH/BD/144534/2019) financed by POPH-QREN and subsidized by the European Science Foundation and Ministério da Ciência, Tecnologia e Ensino Superior. Elsa F. Vieira and Andreia Peixoto acknowledge the FCT for their work contract (CEECIND/03988/2018 and Decree-Law 57/2016, of August 29, changed by Law 57/2017, of July 19, respectively), supported by national funds (OE).

Conflicts of Interest: The authors declare no conflict of interest.

\section{References}

1. Squillaci, G.; Apone, F.; Sena, L.M.; Carola, A.; Tito, A.; Bimonte, M.; Lucia, A.D.; Colucci, G.; Cara, F.L.; Morana, A. Chestnut (Castanea sativa Mill.) industrial wastes as a valued bioresource for the production of active ingredients. Process Biochem. 2018, 64, 228-236. [CrossRef]

2. Alañón, M.E.; Schumacher, R.; Castro-Vázquez, L.; Díaz-Maroto, M.C.; Hermosín-Gutiérrez, I.; Pérez-Coello, M.S. Enological potential of chestnut wood for aging Tempranillo wines Part II: Phenolic compounds and chromatic characteristics. Food Res. Int. 2013, 51, 536-543. [CrossRef]

3. de Vasconcelos, M.C.B.M.; Bennett, R.N.; Quideau, S.; Jacquet, R.; Rosa, E.A.S.; Ferreira-Cardoso, J.V. Evaluating the potential of chestnut (Castanea sativa Mill.) fruit pericarp and integument as a source of tocopherols, pigments and polyphenols. Ind. Crops Prod. 2010, 31, 301-311. [CrossRef] 
4. Reinoso, B.D.; Couto, D.; Moure, A.; Fernandes, E.; Domínguez, H.; Parajó, J.C. Optimization of antioxidants - Extraction from Castanea sativa leaves. Chem. Eng. J. 2012, 203, 101-109. [CrossRef]

5. Vázquez, G.; Fernández-Agulló, A.; Gómez-Castro, C.; Freire, M.S.; Antorrena, G.; González-Álvarez, J. Response surface optimization of antioxidants extraction from chestnut (Castanea sativa) bur. Ind. Crops Prod. 2012, 35, 126-134. [CrossRef]

6. Hooper, L.; Kroon, P.A.; Rimm, E.B.; Cohn, J.S.; Harvey, I.; Le Cornu, K.A.; Ryder, J.J.; Hall, W.L.; Cassidy, A. Flavonoids, flavonoid-rich foods, and cardiovascular risk: A meta-analysis of randomized controlled trials. Am. J. Clin. Nutr. 2008, 88, 38-50. [CrossRef]

7. Mertens-Talcott, S.U.; Lee, J.H.; Percival, S.S.; Talcott, S.T. Induction of cell death in Caco-2 human colon carcinoma cells by ellagic acid rich fractions from muscadine grapes (Vitis rotundifolia). J. Agric. Food Chem. 2006, 54, 5336-5343. [CrossRef]

8. Veluri, R.; Singh, R.P.; Liu, Z.; Thompson, J.A.; Agarwal, R.; Agarwal, C. Fractionation of grape seed extract and identification of gallic acid as one of the major active constituents causing growth inhibition and apoptotic death of DU145 human prostate carcinoma cells. Carcinogenesis 2006, 27, 1445-1453. [CrossRef]

9. Chua, L.S. A review on plant-based rutin extraction methods and its pharmacological activities. J. Ethnopharmacol. 2013, 150, 805-817. [CrossRef]

10. Kicel, A.; Owczarek, A.; Michel, P.; Skalicka-Woźniak, K.; Kiss, A.K.; Olszewska, M.A. Application of HPCCC, UHPLC-PDA-ESI-MS3 and HPLC-PDA methods for rapid, one-step preparative separation and quantification of rutin in Forsythia flowers. Ind. Crops Prod. 2015, 76, 86-94. [CrossRef]

11. Morana, A.; Squillaci, G.; Paixão, S.; Alves, L.; Cara, F.; Moura, P. Development of an energy biorefinery model for chestnut (Castanea sativa Mill.) shells. Energies 2017, 10, 1504. [CrossRef]

12. Aires, A.; Carvalho, R.; Saavedra, M.J. Valorization of solid wastes from chestnut industry processing: Extraction and optimization of polyphenols, tannins and ellagitannins and its potential for adhesives, cosmetic and pharmaceutical industry. Waste Manag. 2016, 48, 457-464. [CrossRef] [PubMed]

13. Chemat, F.; Rombaut, N.; Sicaire, A.G.; Meullemiestre, A.; Fabiano-Tixier, A.S.; Abert-Vian, M. Ultrasound assisted extraction of food and natural products. Mechanisms, techniques, combinations, protocols and applications. A review. Ultrason. Sonochem. 2017, 34, 540-560. [CrossRef] [PubMed]

14. Wen, C.; Zhang, J.; Zhang, H.; Dzah, C.S.; Zandile, M.; Duan, Y.; Ma, H.; Luo, X. Advances in ultrasound assisted extraction of bioactive compounds from cash crops-A review. Ultrason. Sonochem. 2018, 48, 538-549. [CrossRef]

15. Azmir, J.; Zaidul, I.S.M.; Rahman, M.M.; Sharif, K.M.; Mohamed, A.; Sahena, F.; Jahurul, M.H.A.; Ghafoor, K.; Norulaini, N.A.N.; Omar, A.K.M. Techniques for extraction of bioactive compounds from plant materials: A review. J. Food Eng. 2013, 117, 426-436. [CrossRef]

16. Lianfu, Z.; Zelong, L. Optimization and comparison of ultrasound/microwave assisted extraction (UMAE) and ultrasonic assisted extraction (UAE) of lycopene from tomatoes. Ultrason. Sonochem. 2008, 15, 731-737. [CrossRef]

17. Barba, F.J.; Zhu, Z.; Koubaa, M.; Sant'Ana, A.S.; Orlien, V. Green alternative methods for the extraction of antioxidant bioactive compounds from winery wastes and by-products: A review. Trends Food Sci. Technol. 2016, 49, 96-109. [CrossRef]

18. Pasrija, D.; Anandharamakrishnan, C. Techniques for Extraction of Green Tea Polyphenols: A Review. Food Bioprocess Technol. 2015, 8, 935-950. [CrossRef]

19. Panda, D.; Manickam, S. Cavitation technology-The future of greener extraction method: A review on the extraction of natural products and process intensification mechanism and perspectives. Appl. Sci. 2019, 9, 766. [CrossRef]

20. Suslick, K.S. Sonochemistry. Science 1990, 247, 1439. [CrossRef]

21. Kek, S.P.; Chin, N.L.; Yusof, Y.A. Direct and indirect power ultrasound assisted pre-osmotic treatments in convective drying of guava slices. Food Bioprod. Process. 2013, 91, 495-506. [CrossRef]

22. Medina-Torres, N.; Ayora-Talavera, T.; Espinosa-Andrews, H.; Sánchez-Contreras, A.; Pacheco, N. Ultrasound Assisted Extraction for the Recovery of Phenolic Compounds from Vegetable Sources. Agronomy 2017, 7, 47. [CrossRef]

23. Bruno, S.F.; Ekorong, F.J.A.A.; Karkal, S.S.; Cathrine, M.S.B.; Kudre, T.G. Green and innovative techniques for recovery of valuable compounds from seafood by-products and discards: A review. Trends Food Sci. Technol. 2019, 85, 10-22. [CrossRef] 
24. Pan, Z.; Qu, W.; Ma, H.; Atungulu, G.G.; McHugh, T.H. Continuous and pulsed ultrasound-assisted extractions of antioxidants from pomegranate peel. Ultrason. Sonochem. 2012, 19, 365-372. [CrossRef]

25. Pingret, D.; Fabiano-Tixier, A.-S.; Bourvellec, C.L.; Renard, C.M.G.C.; Chemat, F. Lab and pilot-scale ultrasound-assisted water extraction of polyphenols from apple pomace. J. Food Eng. 2012, 111, 73-81. [CrossRef]

26. Re, R.; Pellegrini, N.; Proteggente, A.; Pannala, A.; Yang, M.; Rice-Evans, C. Antioxidant activity applying an improved ABTS radical cation decolorization assay. Free Radic. Biol. Med. 1999, 26, 1231-1237. [CrossRef]

27. Benzie, I.F.; Strain, J.J. Ferric reducing/antioxidant power assay: Direct measure of total antioxidant activity of biological fluids and modified version for simultaneous measurement of total antioxidant power and ascorbic acid concentration. Methods Enzymol. 1999, 299, 15-27.

28. Barros, L.; Baptista, P.; Ferreira, I.C.F.R. Effect of Lactarius piperatus fruiting body maturity stage on antioxidant activity measured by several biochemical assays. Food Chem. Toxicol. 2007, 45, 1731-1737. [CrossRef]

29. Singleton, V.L.; Rossi, J.A.J. Colorimetry of total phenolics with phosphomolybdic-phosphotungstic acid reagents. Am. J. Enol. Vit. 1965, 16, 144-158.

30. Gomes, A.; Fernandes, E.; Silva, A.M.S.; Santos, C.M.M.; Pinto, D.C.G.A.; Cavaleiro, J.A.S.; Lima, J.L.F.C. 2-Styrylchromones: Novel strong scavengers of reactive oxygen and nitrogen species. Bioorg. Med. Chem. 2007, 15, 6027-6036. [CrossRef]

31. Marangi, F.; Pinto, D.; de Francisco, L.; Alves, R.C.; Puga, H.; Sut, S.; Dall'Acqua, S.; Rodrigues, F.; Oliveira, M.B.P.P. Hardy kiwi leaves extracted by multi-frequency multimode modulated technology: A sustainable and promising by-product for industry. Food Res. Int. 2018, 112, 184-191. [CrossRef] [PubMed]

32. de Francisco, L.M.B.; Pinto, D.; Rosseto, H.C.; Toledo, L.A.S.; Santos, R.S.; Costa, P.; Rodrigues, F.; Oliveira, M.B.P.P.; Sarmento, B.; Bruschi, M.L. Development of a microparticulate system containing Brazilian propolis by-product and gelatine for ascorbic acid delivery: Evaluation of intestinal cell viability and radical scavenging activity. Food Funct. 2018, 9, 4194-4206. [CrossRef] [PubMed]

33. Prasad, K.N.; Hassan, F.A.; Yang, B.; Kong, K.W.; Ramanan, R.N.; Azlan, A.; Ismail, A. Response surface optimisation for the extraction of phenolic compounds and antioxidant capacities of underutilised Mangifera pajang Kosterm. peels. Food Chem. 2011, 128, 1121-1127. [CrossRef]

34. Negrão Murakami, A.N.; de Mello Castanho Amboni, R.D.; Prudêncio, E.S.; Amante, E.R.; de Moraes Zanotta, L.; Maraschin, M.; Cunha Petrus, J.C.; Teófilo, R.F. Concentration of phenolic compounds in aqueous mate (Ilex paraguariensis A. St. Hil) extract through nanofiltration. LWT Food Sci. Technol. 2011, 44, 2211-2216. [CrossRef]

35. Chisté, R.C.; Mercadante, A.Z.; Gomes, A.; Fernandes, E.; Lima, J.L.F.C.; Bragagnolo, N. In vitro scavenging capacity of annatto seed extracts against reactive oxygen and nitrogen species. Food Chem. 2011, 127, 419-426. [CrossRef]

36. Gironi, F.; Piemonte, V. Temperature and solvent effects on polyphenol extraction process from chestnut tree wood. Chem. Eng. Res. Des. 2011, 89, 857-862. [CrossRef]

37. Wong, S.P.; Leong, L.P.; William Koh, J.H. Antioxidant activities of aqueous extracts of selected plants. Food Chem. 2006, 99, 775-783. [CrossRef]

38. Barreira, J.C.M.; Ferreira, I.C.F.R.; Oliveira, M.B.P.P.; Pereira, J.A. Antioxidant activities of the extracts from chestnut flower, leaf, skins and fruit. Food Chem. 2008, 107, 1106-1113. [CrossRef]

39. Nazzaro, M.; Mottola, M.; Cara, F.; Del Monaco, G.; Aquino, R.; Volpe, M. Extraction and characterization of biomolecules from agricultural wastes. Chem. Eng. Trans. 2012, 27, 331-336.

40. Rodrigues, F.; Santos, J.; Pimentel, F.B.; Braga, N.; Palmeira-de-Oliveira, A.; Oliveira, M.B.P.P. Promising new applications of Castanea sativa shell: Nutritional composition, antioxidant activity, amino acids and vitamin E profile. Food Funct. 2015, 6, 2854-2860. [CrossRef]

41. Almeida, I.F.; Valentão, P.; Andrade, P.B.; Seabra, R.M.; Pereira, T.M.; Amaral, M.H.; Costa, P.C.; Bahia, M.F. In vivo skin irritation potential of a Castanea sativa (Chestnut) leaf extract, a putative natural antioxidant for topical application. Basic Clin. Pharmacol. Toxicol. 2008, 103, 461-467. [CrossRef] [PubMed]

42. Pinto, D.; Rodrigues, F.; Braga, N.; Santos, J.; Pimentel, F.B.; Palmeira-de-Oliveira, A.; Oliveira, M.B.P.P. The Castanea sativa bur as a new potential ingredient for nutraceutical and cosmetic outcomes: Preliminary studies. Food Funct. 2017, 8, 201-208. [CrossRef] [PubMed]

43. Albergaria, E.T.; Oliveira, A.F.M.; Albuquerque, U.P. The effect of water deficit stress on the composition of phenolic compounds in medicinal plants. South Afr. J. Bot. 2020, 131, 12-17. [CrossRef] 
44. Dias, M.I.; Sousa, M.J.; Alves, R.C.; Ferreira, I.C.F.R. Exploring plant tissue culture to improve the production of phenolic compounds: A review. Ind. Crops Prod. 2016, 82, 9-22. [CrossRef]

45. Barreira, J.C.; Ferreira, I.C.F.R.; Oliveira, M.B.P.P.; Pereira, J.A. Antioxidant potential of chestnut (Castanea sativa L.) and almond (Prunus dulcis L.) by-products. Food Sci. Technol. Int. 2010, 16, 209-216. [CrossRef]

46. Oliveira, I.; Sousa, A.; Ferreira, I.C.F.R.; Bento, A.; Estevinho, L.; Pereira, J.A. Total phenols, antioxidant potential and antimicrobial activity of walnut (Juglans regia L.) green husks. Food Chem. Toxicol. 2008, 46, 2326-2331. [CrossRef]

47. Pelvan, E.; Olgun, E.Ö.; Karadağ, A.; Alasalvar, C. Phenolic profiles and antioxidant activity of Turkish Tombul hazelnut samples (natural, roasted, and roasted hazelnut skin). Food Chem. 2018, 244, 102-108. [CrossRef]

48. Fernández-Agulló, A.; Freire, M.S.; Antorrena, G.; Pereira, J.A.; González-Álvarez, J. Effect of the extraction technique and operational conditions on the recovery of bioactive compounds from chestnut (Castanea sativa) bur and shell. Sep. Sci. Technol. 2014, 49, 267-277. [CrossRef]

49. Dinis, L.T.; Oliveira, M.M.; Almeida, J.; Costa, R.; Gomes-Laranjo, J.; Peixoto, F. Antioxidant activities of chestnut nut of Castanea sativa Mill. (cultivar 'Judia') as function of origin ecosystem. Food Chem. 2012, 132, 1-8. [CrossRef]

50. Pinto, D.; Diaz Franco, S.; Silva, A.M.; Cupara, S.; Koskovac, M.; Kojicic, K.; Soares, S.; Rodrigues, F.; Sut, S.; Dall'Acqua, S.; et al. Chemical characterization and bioactive properties of a coffee-like beverage prepared from Quercus cerris kernels. Food Funct. 2019, 10, 2050-2060. [CrossRef]

51. Orak, H.H.; Isbilir, S.S.; Yagar, H. Determination of antioxidant properties of lyophilized olive leaf water extracts obtained from 21 different cultivars. Food Sci. Biotechnol. 2012, 21, 1065-1074. [CrossRef]

52. Almeida, I.F.; Fernandes, E.; Lima, J.L.; Costa, P.C.; Bahia, M.F. Protective effect of Castanea sativa and Quercus robur leaf extracts against oxygen and nitrogen reactive species. J. Photochem. Photobiol. B 2008, 91, 87-95. [CrossRef] [PubMed]

53. Ribeiro, A.B.; Berto, A.; Ribeiro, D.; Freitas, M.; Chisté, R.C.; Visentainer, J.V.; Fernandes, E. Stem bark and flower extracts of Vismia cauliflora are highly effective antioxidants to human blood cells by preventing oxidative burst in neutrophils and oxidative damage in erythrocytes. Pharm. Biol. 2015, 53, 1691-1698. [CrossRef] [PubMed]

54. Rodrigues, J.V.; Gomes, C.M. Enhanced superoxide and hydrogen peroxide detection in biological assays. Free Radic. Biol. Med. 2010, 49, 61-66. [CrossRef]

55. Forester, S.C.; Lambert, J.D. The role of antioxidant versus pro-oxidant effects of green tea polyphenols in cancer prevention. Mol. Nutr. Food Res. 2011, 55, 844-854. [CrossRef]

56. Mehta, S.K.A.G.; Sivakumar, J.T. Chapter 4-Members of Antioxidant Machinery and Their Functions. In Basic Principles and Clinical Significance of Oxidative Stress; Gowder, E.S.J.T., Ed.; IntechOpen: London, UK, 2015; pp. 59-85.

57. Comandini, P.; Lerma-Garcia, M.J.; Simo-Alfonso, E.F.; Toschi, T.G. Tannin analysis of chestnut bark samples (Castanea sativa Mill.) by HPLC-DAD-MS. Food Chem. 2014, 157, 290-295. [CrossRef]

58. Groeber, F.; Holeiter, M.; Hampel, M.; Hinderer, S.; Schenke-Layland, K. Skin tissue engineering-in vivo and in vitro applications. Adv. Drug Deliv. Rev. 2011, 63, 352-366. [CrossRef]

59. MacNeil, S. Progress and opportunities for tissue-engineered skin. Nature 2007, 445, 874-880. [CrossRef] [PubMed]

60. Meunier, V.; Bourrié, M.; Berger, Y.; Fabre, G. The human intestinal epithelial cell line Caco-2; pharmacological and pharmacokinetic applications. Cell Biol. Toxicol. 1995, 11, 187-194. [CrossRef]

61. Pinto, D.; Braga, N.; Rodrigues, F.; Oliveira, M.B.P.P. Castanea sativa bur: An undervalued by-product but a promising cosmetic ingredient. Cosmetics 2017, 4, 50. [CrossRef]

62. Cacciola, N.A.; Squillaci, G.; D’Apolito, M.; Petillo, O.; Veraldi, F.; La Cara, F.; Peluso, G.; Margarucci, S.; Morana, A. Castanea sativa Mill. shells aqueous extract exhibits anticancer properties inducing cytotoxic and pro-apoptotic effects. Molecules 2019, 24, 3401. [CrossRef] [PubMed]

(C) 2020 by the authors. Licensee MDPI, Basel, Switzerland. This article is an open access article distributed under the terms and conditions of the Creative Commons Attribution (CC BY) license (http://creativecommons.org/licenses/by/4.0/). 